\title{
E_Newspaper Literacy-Based Learning Model to Optimize Students' Critical Thinking/Problem Solving in Higher Education Institutions
}

\author{
Dessi Susanti ${ }^{1 *}$, Nurzi Sebrina ${ }^{2}$, Armiati $^{3}$, and Rose Rahmidani ${ }^{4}$ \\ ${ }^{1234}$ Economic Faculty, Universitas Negeri Padang, Padang, Indonesia. \\ *Corresponding author. Email: dessisusanti@fe.unp.ac.id
}

\begin{abstract}
The aims of this research are: 1) To design a learning model for the Introduction to Accounting course based on E_Newspaper Literacy to optimize students' Critical Thinking / Problem Solving Skills in higher education institutions, 2) To produce a valid learning model for the Introduction to Accounting course based on to optimize students' Critical Thinking / Problem Solving Skills in higher education institutions. E_Newspaper Literacy-Based Learning Model were developed by using ADDIE model (Analyze, Design, Develop, Implement, and Evaluate). For the first year of the research, it only focuses on the development stage. The instruments of data employed were in the form of observation sheets and questionnaires. The developed model was validated by experts in education, accounting, language, and info-graphics. The feedback and suggestions to improve the model were given in written forms. The results of this study are 1) The current learning model used for the Introduction to Accounting course has not yet optimized students' critical thinking / problem solving skills, 2) E_Newspaper Literacy-Based Learning Model was designed to optimize students' Critical Thinking / Problem Solving Skills, 3) The valid design of E_Newspaper Literacy-Based Learning Model for Introduction to Accounting course to optimize students' Critical Thinking / Problem Solving Skills has been achieved.
\end{abstract}

Keywords: Learning Model, E_Newspaper Literacy, Critical Thinking / Problem Solving, introduction to accounting

\section{INTRODUCTION}

Central Bureau of Statistics released Indonesia's employment conditions as of February 2019. The data shows that the unemployment rate has decreased to 5.01 percent or reduced by 50 thousand people over the past year. The Open Unemployment Rate as of February 2019 is probably 6.82 million people. It shows a downward trend in the open unemployment rate since February 2016, although unemployment has decreased, but from the level of education, more graduate diploma and university are jobless.

The factor considered to cause the increasing of educated unemployment is the inability of scholars to compete in the world of work. This is due to their inability to adapt, innovate, be critical and accountable as demanded by the company (Ledward, Hirata, 2011).

Jacskson (2016) revealed that many entrepreneurs are not satisfied with the skills that scholars have, because the lack of critical thinking skills. This skill is very important to make arguments, decisions or solve problems and adapt (Gistituati, 2018), at once, this is the demand for 21st century skills discussed in the 2016 World Economic Forum.

Critical thinking ability can be developed through introduction to accounting learning with Problem Based Learning model, which can improve critical thinking / problem solving skills (Haryani \& Desti, 2012; Karim, 2011; Richland \& Begolli, 2016; Samo et.all, 2017; Syaban, 2010). Tanujaya et.all, 2017; Arnold, 2009). The reason for using introduction to accounting learning is because the skills are numerical. Many research results reveal that calculating abilities contribute to success in business field (Dawson, 2014; Espey \& Walker, 2012; Fajriah, et.all, 2015; Nasution, 2015; Olukemi \& Gbenga, 2016; Uka, 2015, Fasko, 2001). By mastering the introduction to accounting learning, students will be better in solving various problems in the business field. At last, they will succeed in the world of work.

Problem based learning with newspapers was discussed in 2012 in the World Conference on Economics Education (WCEE) about "Context-Based Economics Education and Learning with Newspaper Based and other Authentic Learning Problems at Bahcesehir University Istanbul Turkey (Muller, 2012) stated that economic learning with problems based on newspaper and real-life contexts can enhance critical thinking and problem-solving skills. 
Based on the description above, it is important to conduct a research related to E_Newspaper LiteracyBased Learning Model to Optimize Students Critical Thinking/Problem Solving in Higher Education Institutions.

The aims of this research are: 1) To design a learning model for the Introduction to Accounting course based on E_Newspaper Literacy to optimize students' Critical Thinking / Problem Solving Skills in higher education institutions, 2) To produce a valid learning model for the Introduction to Accounting course based on to optimize students' Critical Thinking / Problem Solving Skills in higher education institutions.

PBL is an active learning model based on the use of unstructured problems as a stimulus for learning (Barrows \& Tamblyn, 1980). The problems presented in problem-based learningare contextual problems and close to everyday life (Kyu \& Ph, 2015).

The components of PBL are unstructured problem in everyday life (structured problems), partian information 1 (partial information), allowing students to become independent learners in finding problem solutions (question that belong to student), that have various solutions and require groups effort to solve problems (Duch, et.all, 2001).

There are five stages of learning activities on PBL, such as student orientation of the problem, organizing students to learn, guiding individual and group investigations, developing and presenting work, analyzing and evaluating the problem-solving process (Arends, 2008).

News literacy is the ability to apply critical thinking skills in assessing the reliability and credibility of news reports, whether in printed media, TV, or the Internet (Press, 2015). The ultimate goal of news literacy for students is to become more regular and more skeptical newsreaders, observers, and listeners who are able to determine whether information is reliable enough to reach a conclusion, make decisions, or take action.

In education, newspapers have been widely used. The research entitled "Newspaper as tools of Literacy in Uganda, a case study Newspaper Program in Education (NiE)" reveals that in $\mathrm{NiE}$, the use of newspapers as a source of education for any subject. The newspapers can provide lessons in reading, mathematics, politics, science, social studies, geography and critical thinking (Namata, 2010). NiE can be done at all levels of education and the lessons can be fit the national school curriculum. There are several things that must be done in implementing the Newspaper Literacy cycle, including giving different role models to students in a small group, providing a journal to record information about predetermined roles (Shaw, 2004). Students \& lecturers can select an article to read, when students read the article with a particular focus and write important notes in their journals, they are ready to share information in their small group. Besides retelling the journal and asking questions to other students, readers should be able to add comments to other student information sections. After reporting their area of expertise and no further comment, the discussion leader will summarize what happened in the group. On newspaper literacy should be done by 3 to 5 students per group.

There are six basic elements in critical thinking known by the acronym FRISCO (Focus, Reason, Inference, Situation, Clarity, Overview) (Julita, 2014). Problem solving is a planned process that must be done in order to get a certain solution to a problem that may not be obtained immediately (Liu, 2005). Problem solving is an attempt to find a way out of a difficulty (Lepinski, 2005). The results revealed that, "the problem solving process is an important element in combining real life problems" (Maryam, et. All, 2013). The stages of problem solving are 1) Understand the problem 2) Devise a plan), 3) Carry out the plan, 4) Looking back (Polya, 1973).

Research based on problem solving and critical thinking that has been done by previous researchers is mostly in the fields of science and mathematics, while this research is about accounting. Mathematics and accounting have the same scientific characteristics, that is numeracy. The mathematical perspective has been widely used in presenting the facts of life. Based on the history of accounting in Summa written by Pacioli, it is possible that Pacioli discussed accounting standards in mathematics books, because accounting, especially the pairwise recording system, is an application of algebra. In discussing the relationship between accounting and mathematics, accounting and mathematics definitions can be used (Murphy, 2013).

\section{METHODS}

This study was developed by using ADDIE Model. firstly, the researcher conducted the analysis. Secondly, the researcher designs the product. Thirdly, the researcher develops the product. Fourthly, the researcher implements a product that has been developed in a limited way. Finally, the researcher evaluates the products that have been implemented (Branch, 2009). However, at each stage, researchers must revise according to the results found in each research process. For this first year research, the researcher only reached the third stage, such as developing the product and doing the validity test.

This research is located at the Faculty of Economics, Padang State University. This research was conducted 
on students who had taken introduction to accounting courses 1. Data collection for the achievement of research objectives are by observation, in-depth interviews (structured and unstructured). The data obtained were analyzed descriptively, qualitatively and quantitatively.

Data collection was carried out by observing, documenting, and interviewing the lecturers, students of the Faculty of Economics, education and accounting experts. To ensure the validity of the data, a validity test was validated by experts of accounting, language, and education

\section{RESULTS AND DISCUSSION}

In developing this model, three products were produced, such as model books, lecturers' books and student books.

\section{Results of Preliminary Research (Preliminary Analysis)}

The results of the preliminary analysis that have been done are as follows:

\section{Needs Analysis Results}

Interviews result of lecturers

The results showed that 4 out of 5 interviewed lecturers stated that they had never heard about newspaper literacy, and none of them had ever directed students to look for accounting cases in newspapers. All 1 interviewed lecturers used learning tools, in the form of textbooks, handouts and none of them used SAP, besides that, all interviewed lecturers generally used teaching materials from the internet. They admitted that the learning tools were quite helpful, but all agreed that the existing tools were not maximal in supporting the improvement of student accounting skills. 2 lecturers admitted that they were not familiar with the learning model, and 2 more lecturers already knew several learning models. Lecturers who are not familiar with the model admit that they mostly use the lecture method and ask students to discuss.

A lecturer who was familiar with the model stated that he had applied the PBL model, and another lecture had used a combination of cooperative learning with lectures method. The lecturers' answers to the most difficult content in introduction to accounting course and requiring special attention were varied, a lecturer said about accounting equations, a lecturer said about accounts and trial balance, a lecturer said about journals and another one said about posting. Lecturers tend to direct the context of introducing to accounting into the context of everyday life such as service businesses that are close to the daily lives of students such as salons, workshop businesses etc. In process of introduction to accounting, four lecturers argued that it was more difficult for students to do the interpretation stage. All lecturers who were interviewed used questions in essay form.

Interviews Results of Students

The results showed that 3 students liked to study in groups because they could exchange ideas with fellow students in completing assignments, while 1 student preferred lecturing method because not all members were willing to actively learn in groups. In line with the lecturers' answers, all students interviewed stated that the learning tools used had been quite helpful in learning but had not been maximal in supporting the improvement of student accounting skills. The students argued that they need a learning model that supports interaction among students and interaction between students and lecturers. The responses to questions about students' expectations for learning tools were varied, one student hoped that there would be modules or student activity sheets that were not too fixated on theory, but more exercises for problem solving, and more examples that were close to everyday life.

Three students admitted that they had difficulty in understanding the accounting equation, while 1 student admitted that it was difficult to understand accounts and journals. The students have the same opinion, that they supported the use of the accounting context in everyday life. All students interviewed admitted that the difficulties in accounting process was at the interpretation stage.

\section{Curriculum Analysis}

In Law number 2 of 1989 concerning the National Education System in article 1 point 9 it is stated that the curriculum is: (1) a set of plans and arrangements regarding content and (2) learning materials, and (3) the method used as a guidance for implementing learning activities. The curriculum analysis is done to obtain the result of learning model is in accordance with the introduction to accounting course material in the applicable curriculum, especially related to the supporting components of the model. An introduction to accounting course is a course in which has the basics of accounting needed to understand the problems of corporate financial statements. The material taught is adjusted to the expected Learning Outcomes in learning.

The Lecture Course Unit (SAP) used is sufficient to support student orientation to service company problems that are close to everyday life. Curriculum analysis on introduction to accounting courses can be seen in the following table. 
Table 1. The Result of curriculum Analysis

\begin{tabular}{|c|c|}
\hline $\begin{array}{l}\text { The component of } \\
\text { curriculum }\end{array}$ & Result \\
\hline & Objective \\
\hline $\begin{array}{l}\text { The objectives } \\
\text { should reflect: } \\
\text { 1. National } \\
\text { education } \\
\text { objectives } \\
\text { 2. Institutional goals } \\
\text { (attitudes, } \\
\text { spiritual, social } \\
\text { attitudes, } \\
\text { knowledge, and } \\
\text { skills) }\end{array}$ & $\begin{array}{l}\text { 1. The curriculum reflects goals } \\
\text { National education, that is } \\
\text { developing abilities and } \\
\text { shaping dignified national } \\
\text { character and civilization in } \\
\text { order to educate the nation's } \\
\text { life, aims to develop the } \\
\text { potential of students to } \\
\text { become human beings who } \\
\text { believe and fear of God } \\
\text { Almighty, have noble } \\
\text { character, healthy, } \\
\text { knowledgeable, capable, } \\
\text { creative, independent, and } \\
\text { become democratic and } \\
\text { responsible citizens. This can } \\
\text { be seen from the Learning } \\
\text { Outcomes } \\
\text { 2. Institutional objectives have } \\
\text { been reflected in Learning } \\
\text { Outcome aspects of } \\
\text { knowledge, attitudes and } \\
\text { psychomotor }\end{array}$ \\
\hline \multicolumn{2}{|c|}{ The component of content } \\
\hline $\begin{array}{l}\text { The Content } \\
\text { component relates to } \\
\text { the subject of } \\
\text { lectures taught in } \\
\text { class / material } \\
\text { learning to achieve } \\
\text { goals }\end{array}$ & $\begin{array}{l}\text { The material taught is service } \\
\text { company financial material with } \\
\text { a time allocation of } 16 \text { credits } \\
\text { and it can be studied }\end{array}$ \\
\hline
\end{tabular}

\begin{tabular}{|c|c|}
\hline \multicolumn{2}{|c|}{ The component of method } \\
\hline $\begin{array}{l}\text { 1. It Must be in } \\
\text { accordance with } \\
\text { the material to be } \\
\text { given and the } \\
\text { goals to be } \\
\text { achieved. } \\
\text { Based on real } \\
\text { problems in } \\
\text { everyday life } \\
\text { 2. Learning }\end{array}$ & $\begin{array}{l}\text { 1. Problem-based learning } \\
\text { model } \\
\text { 2. Student centered method }\end{array}$ \\
\hline \multicolumn{2}{|c|}{ The component of evaluation } \\
\hline $\begin{array}{l}\text { Knowledge } \\
\text { evaluation tool } \\
\text { 1. The written test } \\
\text { instrument is in } \\
\text { the form of } \\
\text { multiple choice, } \\
\text { entries and }\end{array}$ & $\begin{array}{l}\text { Knowledge evaluation tool } \\
\text { 1. The written test instrument is } \\
\text { in the form of multiple choice } \\
\text { and descriptions. The } \\
\text { description instrument is } \\
\text { equipped with scoring } \\
\text { guidelines. }\end{array}$ \\
\hline
\end{tabular}

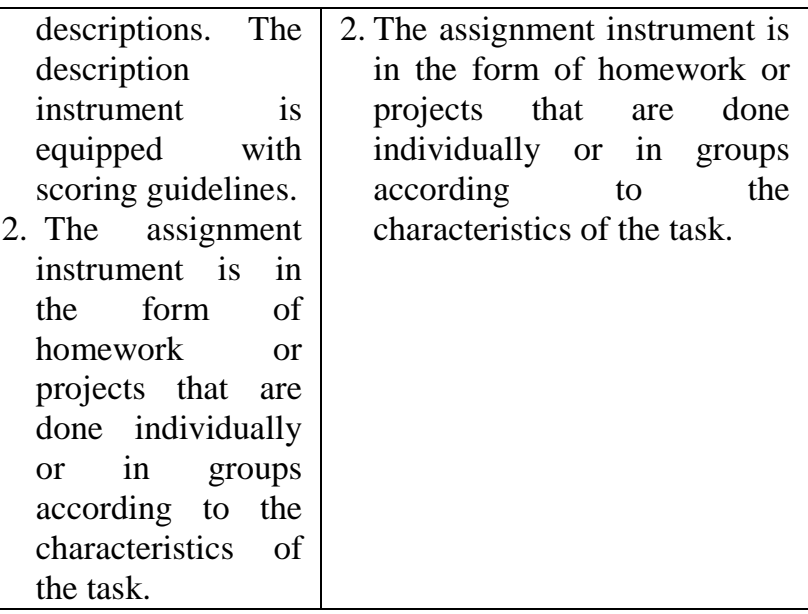

Based on the question and answer conducted to lecturers who teach introduction to accounting courses, it shows that: the lecturer is not well prepared for lesson plan, for example in desaining SAP for each meeting The SAP used are the of previous year or existing SAP from other lecturers. Furthermore, it is known that the substance of existing SAP still does not use a learning model or approach, while, in carrying out learning, lecturers are required to be able to apply learning models or approaches that are in accordance with the characteristics of students and learning material which is based on real problems in everyday life. The learning activities that are designed also not in accordance with what is expected by the curriculum, as in the introduction, lecturers still not make perceptions and motivations.

Furthermore, the implementation of learning is not as expected. it requires the use of good models and approaches in supporting the achievement of learning objectives. Based on observations, the implementation of learning tends to be centered on lecturers (teacher centered) so that it tends to provide less opportunity for students to develop creative thinking. Students are also less interactive in the learning process because the learning model or approach used by the lecturer has not provided a vehicle for creating an interactive learning atmosphere, even there are still SAP that do not include learning models or approaches.

Analysis of the assessment tools, it was found that the assessment was more emphasized on written assessments which included knowledge competencies only but paid less attention to students' attitudes and skills. This condition is not in accordance with Permendikbud No. 66. 2013, which states that the assessment must describe student competencies for the three dimensions, such as attitudes, knowledge, and skills with measurable formats and instruments

Problems in this lesson plan can be solved by 
analyzing the curriculum that has been done. The results of curriculum analysis can be used as a reference in designing a well-structured learning so that learning becomes more meaningful for students

\section{Analysis of student characteristics}

The purpose of the learner analysis is the stage of studying the characteristics of students who will be used as a reference in determining the appropriate learning model / approach / method / media. These characteristics include academic ability, cognitive development, and individual and group skills. The activity of analyzing the behavior and initial characteristics of students in the development of learning is an approach that accepts students as they are and develops a learning system based on the circumstances of these students. Therefore, the activity of analyzing the behavior and initial characteristics of students is a process to find out which behavior is controlled by students before participating in the learning process, identification of student behavior is done by looking at the input of students taking Introduction to Accounting courses.

The results of these student characteristics provide an overview of product design and content coverage in product support systems, especially in student books. Thus, the model and supporting products are developed according to the character of the student so that the product can facilitate students such as understandable language, use of letters, placement of material, sample questions and exercise questions that stimulate their curiosity. Besides that, it is also used as a basis for improving student problem solving skills.

Students of the Faculty of Economics, who are generally students from State Senior High Schools from various cities and districts in West Sumatra, both majoring in Science, Social Sciences and Accounting Vocational High Schools. They are quite interested in learning an introduction to accounting.

\section{Student Accounting Skills}

Characteristics of students showed from the economic ability of accounting is quite varied. Students with low ability (10\%), students with moderate ability $(80 \%)$, and students with low ability (10\%).

\section{Response to Learning}

Based on Students response of learning, there are three things that display high scores, such as for items interested in learning begins with a problem (70\%), requiring colleagues to elaborate on course materials to solve introductory accounting problems (80\%), and interested in economics news as a source of information to assist in solving introduction to accounting problems
$(80 \%)$. For the other three items, the scores obtained were low, it related to suggesting ideas, finding new ideas and the ability to elaborate on resources or lecture materials for problem solving.

\section{Design Results}

The results of the product design are in the form of a learning model which is written into a model book, and a support system in the form of a lecturer book and a student book. Details of the design of model books, lecturers' books and student books are described as follows.

\section{Model Book}

Cover

The design of the model book is done by creating the cover design, selecting letters, spacing, and the content of the model book. The letters and spacing chosen for the model book are Times New Roman letters. Typing space in the selected book is 1.5 spaces.

Systematics

The model book is written briefly so that it can be easily understood by the lecturer to be applied to Introduction to Accounting course in higher education institutions. This model book is organized into several parts such as an introduction and a table of contents at the beginning. The content consists of rational models, supporting theories, model components and closings. The closing consists of conclusions and suggestions. At the end, there is a bibliography which is the reference source for the model book.

Content

The rational model describes the needs and reasons for developing the model. Supporting theory contains theories that support model development and characteristics of introductory accounting learning. The model components consist of the initial model syntax and the syntax of the model after it has been developed, a social system that describes the interaction between lecturers and students during learning, reaction principles, support systems, instructional impacts and accompaniment impacts.

\section{Lecturer Books \\ Letters and Spaces}

The letters chosen for lecturers' books are as same as model books, times new roman letters and typing is done in 1 space.

\section{Systematics}

Lecturer books are prepared based on the needs of the lecturers in performing learning. Typically, a systematic book, at the beginning consist of introduction and a table of contents. The beginning of the book complete with a guidance for using lecturers' book. In 
the part of content, contains the syllabus, lesson plans, teaching materials, student activity observation sheets and rubrics of assessment. The teaching material consists of news illustrations, examples of questions and discussions on the application of roots, ranks and logarithms, questions and keys for group assignments, material summaries, questions and keys for discussing individual assignments.

Content

The syllabus contains subject identities, course benefits, course descriptions, competencies consisting of general competences and specific competencies (hard skills and soft skills), number of lecture hours, reading material, assignment forms, assessment criteria and class schedules.

SAP contains subject identities, competency standards (SK), basic competencies (KD), indicators, time allocation, course objectives, subject matter, learning models, activity steps, learning tools and resources and assessment techniques.

The teaching materials are prepared by presenting newspaper news illustrations and accounting concepts that are placed in the process of solving economic problems. In addition, the teaching materials are also given comments or notes that help lecturers to more easily applied newspaper literacy-based learning. Examples of questions given directly in the form of economic problems. The answers for to each question are systematically made to make it easier for students to solve problems more thoroughly and it is supported by the role of students in the newspaper literacy cycle. Group and individual assignments in this lecturer's book are equipped with an answer key or discussion.

In assessing student learning outcomes, the lecturer book is equipped with an assessment rubric to assess students' accounting skills which include the ability to understand concepts, problem solving and accounting contexts. The assessment of student motivation and attitudes was done by distributing questionnaires, while the assessment of learning activities was obtained by observing.

\section{Student Book \\ Cover}

The students' book cover has the same cover design with model books and lecturers' books, the student book also contains cartoons that demonstrate the concept of newspaper literacy.

Letters and Spaces

The letters chosen for student books are times new roman letters to provide uniformity of letters in the three book products produced.

\section{Systematics}

Student books are arranged based on student needs to participate in learning. At the beginning there is an introduction and a table of contents, and a guidance for using student books. In the content, contains learning material with sample questions and lessons, group and individual assignment questions, material summaries and reflection notes. At the end of the book there is a newspaper literacy cycle note sheet, a systematic report on the results of the discussion and a questionnaire on student motivation and attitudes.

\section{Content}

The learning material presented in this book consists of four materials, such as:

- The accounting equation

- Financial reports

- Accounts and trial balances

- Journal and posting

At the beginning of each material presentation is provide an illustration of news from newspapers as a form of illustration that taken and discussed in learning are problems of everyday life that occur in the economic world. The placement of accounting concepts is adjusted to the needs of the problem-solving process, in order to make it easier for students to understand accounting concepts and their use in economics and business.

This book also provides notes to help students understand the material, do discussions and problems solving. The newspaper literacy cycle note sheet provided in this student book is an instrument that students must fill during the problem-solving process while working on group assignments. The systematic report on the results of the discussion is given to guide students to make it easier to present the results of the discussion which will be presented in class discussions.

\section{Develop Stage}

The develop stage is intended to get feedback from experts as revision material before it is used. Formative evaluation in the form of validation tests by experts. Before validation by experts, the instruments used are validated.

The suggestions from the experts are valuable input for product revisions to make them better. There have been several changes, especially related to the addition of the PBL model syntax table. Introduction to accounting newspaper literacy-based, improving the arrangement of teaching materials. In the following expert assessment table, the data presented is in summary form of the results of the expert assessment recapitulation which consists of various aspects and indicators. 
Table 2. Validation Results of Expert Assessment of Products

\begin{tabular}{|c|c|c|c|c|c|c|}
\hline No & Aspect & Book & $\begin{array}{l}\text { Avera } \\
\text { ge } \\
\text { score } \\
\text { from } \\
\text { Expert }\end{array}$ & $\begin{array}{l}\text { Num } \\
\text { ber } \\
\text { of } \\
\text { quest } \\
\text { ions } \\
\end{array}$ & $\begin{array}{l}\text { Ave } \\
\text { rag } \\
\text { e } \\
\text { scor } \\
\text { e }\end{array}$ & $\begin{array}{l}\text { Crite } \\
\text { ria }\end{array}$ \\
\hline \multirow[t]{3}{*}{1} & \multirow{3}{*}{$\begin{array}{l}\text { Grap } \\
\text { hic }\end{array}$} & Model & 30,33 & 8 & 3,79 & \multirow[t]{3}{*}{ Valid } \\
\hline & & Lecturer & 29 & 8 & 3,63 & \\
\hline & & Student & 29,67 & 8 & 3,71 & \\
\hline \multirow[t]{3}{*}{2} & \multirow{3}{*}{$\begin{array}{l}\text { Lang } \\
\text { uage }\end{array}$} & Model & 10,67 & 3 & 3,56 & \multirow[t]{3}{*}{ Valid } \\
\hline & & Lecturer & 16 & 4 & 3,67 & \\
\hline & & Student & 21,67 & 6 & 3,61 & \\
\hline \multirow[t]{3}{*}{3} & \multirow{3}{*}{$\begin{array}{l}\text { Learn } \\
\text { ing }\end{array}$} & Model & 161,33 & 41 & 3,93 & \multirow[t]{3}{*}{ Valid } \\
\hline & & Lecturer & 27 & 7 & 3,86 & \\
\hline & & Student & 30,33 & 8 & 3,79 & \\
\hline \multirow[t]{2}{*}{4} & \multirow{2}{*}{$\begin{array}{l}\text { Cont } \\
\text { ent }\end{array}$} & Lecturer & 14,67 & 4 & 3,67 & \multirow[t]{2}{*}{ Valid } \\
\hline & & Student & 40,33 & 11 & 3,67 & \\
\hline \multicolumn{5}{|c|}{ Total average } & 3,72 & Valid \\
\hline
\end{tabular}

Based on the table above, it is known that experts assessments of model books, lecturers' books and student books are classified as valid. Therefore, the criteria in this development for the valid category have been fulfilled. For the level of the intra-class correlation coefficient on the validity test of the research instrument that has been done, the following SPSS output results are obtained.

Table 3. The result of reliability test Reliability Statistics

\begin{tabular}{|c|c|}
\hline $\begin{array}{c}\text { Cronbach's } \\
\text { Alpha }\end{array}$ & N of Items \\
\hline .774 & 3 \\
\hline
\end{tabular}

Cronbach's alpha value was obtained at $0.774>0.05$, so it can be said that the existing product meets the criteria for being reliable. Furthermore, for the results of the Interclass Correlation Coefficient (ICC) test, the SPSS output is obtained as follows.

Table 4. ICC test results on products Intraclass Correlation Coefficient

\begin{tabular}{|l|l|l|l|l|l|l|l|}
\hline & \multirow{2}{*}{$\begin{array}{c}\text { Intra } \\
\text { Class } \\
\text { Correlation }\end{array}$} & \multicolumn{2}{|c|}{$\begin{array}{c}\text { 95\% Confidence } \\
\text { Interval }\end{array}$} & \multicolumn{3}{|c|}{ Test with True Value 0 } \\
\cline { 3 - 9 } & & $\begin{array}{l}\text { Lower } \\
\text { Bound }\end{array}$ & $\begin{array}{c}\text { Upper } \\
\text { Bound }\end{array}$ & Value & df1 & df2 & Sig \\
\hline Single Measures & $.533^{\mathrm{a}}$ & -.124 & .955 & 4.419 & 3 & 6 & .058 \\
\hline Average Measures & $.744^{\mathrm{c}}$ & -.493 & .985 & 4.419 & 3 & 6 & .058 \\
\hline
\end{tabular}

- The resulting Newspaper Literacy-based

Two-way mixed effects model where people effects are random and measures effects are fixed.

- The estimator is the same, whether the interaction effect is present or not.

- $\quad$ Type $\mathrm{C}$ intraclass correlation coefficients using a consistency definition-the between-measure variance is excluded from the denominator variance.

- This estimate is computed assuming the interaction effect is absent, because it is not estimable otherwise.

The table of ICC test results show that the ICC value is 0.774 . This means that the experts have a high level of consistency in assessing the product.

\section{CONCLUSION}

Based on the research results above, the conclusions of this study are:

- A learning model of Introduction to Accounting based on Newspaper Literacy has been produced in optimizing Critical Thinking / Problem Solving Skills in higher education through the ADDIE development model
Accounting Learning Model has a high level of validity. It obtained a learning model and its supporting system in the form of a valid lecturer book and student book. The validity of the model is viewed from several aspects, namely aspects of the component content, principles and characteristics of model development. As for the model structure in terms of organization, format, and language used. For the results of the validation of lecturers' books and student books, it is reviewed from organizational aspects, format, aspects of material or content description, use of language and illustrations or pictures.

Suggestions of this research are:

- The learning model based on Newspaper Literacy along with lecturer and student books should be used / applied in the learning process to improve students' critical thinking / problem solving skills in Introduction to Accounting course.

- $\quad$ Lecturer books and student books as supporting 
systems / products in the Newspaper Literacybased learning model were developed in odd semesters for the subject of Introduction to Accounting 1 on the subject of Service Companies, it is advisable for further researchers to make or review the next material.

- For lecturers and researchers who want to apply the Newspaper Literacy-based learning model to other materials, they need to develop their own support system in the form of books or other learning tools by paying attention to the components and principles of the Newspaper Literacy-based learning model.

\section{ACKNOWLEDGMENTS}

The authors express their graditute to the Universitas Negeri Padang for funding the study.

\section{REFERENCES}

[1] Arnold, I. (2009). Motivation and Math Skills as Determinants of First-Year Performance in Economic. The Journal of Economic Education, 43(1), hal. 33-47. DOI. 10.1080/00220485.2012.636709.

[2] Arends, Richard. (2008). Learning to Teach. Jogjakarta: Pustaka Pelajar

[3] Barrows, H. S., \& Tamblyn, R. M. (1980). ProblemBased Learning: An Approach to Medical Education. New York: Springer.

[4] Branch, R. M. (2009). Instructional Design-The ADDIE Approach. New York: Springer

[5] Dawson, P. (2014). Skills in Mathematics and Statistics in Economics and Tackling Transition. Helsington: The Higher Education Academy STEM Project Series.

[6] Duch, BJ., Groh, S.E., \& Allen, D.E (2001) Why Problem Based Learning? A case study of instutional change in undergraduate in duch, Groh, \& Allen, (Eds). The Power of Problem Based Learning (pp3-1) sterling, VA: Stylus

[7] Eggen, Paul Don Kouchak. (2012). Strategi dan Model Pembelajaran. Jakarta: PTIndeks.

[8] Espey, M., \& Walker, J. E. (2012). Enhancing Critical Thinking in Economics Using TeamBased Learning Team-Based Learning. Paper disajikan pada Annual Meeting Agricultural \& Apllied Economic Assosiation di Whosingthon State, 12-14 Agustus, 2012.

[9] Fajriah, A.N.; Junaidi, H.; \& Mastum, A. (2015). Pengaruh Hasil Belajar Matematika Terhadap Hasil Belajar Akuntansi Siswa Di SMK. Untan: Program Studi Pendidikan Ekonomi FKIP UNTAN, Pontianak
[10] Fasko, D. (2001). Education and Creativity. Creativity Research Journal, 13(3-4), 317-327.

[11] Gistituati, N. (2018). Rethinking of Higher Education in a Digital Era. Paper dipresentasikan pada International Conference on Innovation in Education (ICoIE) di Universitas Negeri Padang pada 6-7 September 2018.

[12] Haryani, Desti. (2012). Membentuk Siswa Berpikir Kritis Melalui Pembelajaran Matematika. Yogyakarta: Seminar Nasional Matematika dan Pendidikan Matematika.

[13] Julita. (2014). Mengembangkan Kemampuan Berpikir Kritis Matematik melalui Pembelajaran Pencapaian Konsep. Prosiding Seminar Nasional Pendidikan Matematika Program Pasca Sarjana STKIP Siliwangi, 27 November 2014. Bandung.

[14] Karim, A. (2011). Penerapan Metode Penemuan Terbimbing Dalam Pembelajaran Matematika Untuk Meningkatkan Pemahaman Konsep Dan Kemampuan Berfikir Kritis Siswa Sekolah Dasar. Edisi Khusus No. 1, Agustus 2011 hal. 21- 32

[15] Kyu, M., \& Ph. k (2015) Models of Learning Progress in Solving Complex Problems: Expertise Development in Teaching and Learning. contemporary educational physicology:http://doi.org/10.1016/j.cedpsych.2015 .03 .005

[16] Ledward, M. Hirata, J. (2011). Summary of21st Century Skills for tudents and Teachers. Pacific Policy Research Center, Honolulu: Kamehameha School Research and Evaluation.

[17] Liu, Min. (2005). Motivating Students Through Problem-based Learning. University of Texas Austin

[18] Lepinski. (2005). Problem-Based Learning: A New Approach to Teaching, Training \& Developing Employees. Cokie Lepinski, Assistant Communications Manager Marin County Sheriff's Office. [Online]. Tersedia: http://www.sacpd.org/RCPI/ [26 Desember 2008]

[19] Maryam Sajadi, Parvaneh Amiripour, Mohsen Rostamy Malkhalifeh. (2013). The Examining Mathematical Word Problem Solving Ability Under Efficient Representation Aspect. International Scientific Publications and Consulting Services. Journal of Mathematics.

[20] Murphy Smith, (2013), "Luca Pacioli: The Father of Accounting", Murray State University

[21] Muller. (2012). Context-Based Economics Education and Learning with Newspaper Based and Other Authentic Learning Problems

[22] Nasution, H. F. (2015). Urgensi Kemampuan Matematis Dalam Menganalisis Teori -Teori Ekonomi. Al-Masharif, Vol.3, No.2, hal. 100-113 
[23] Namata, W. (2010). Newspapers as Tools of Literacy in Ugandaa Case Study of Daily Monitor's Newspapers in Education (Nie) Programme Addressing Literacy-Related Issues in Uganda's Primary Education. University of Oslo.

[24] Olukemi \& Gbenga (2016). Relevance of mathematics education to enterpreneurship skills acquisition towards the realization of vision 2020 . International Journal for CrossDisciplinary Subject in Education (IJCDSE), Volume 7, Issue 2, hal. 2768-2773.

[25] Press, J. (2015). Toward 2020: New Directions in Journalism Education. Canada: Ryerson Journalism Research Centre.

[26] Polya, G. (1973). How to Solve it. New Jersey: Princeton University Press.

[27] Richland, L. \& Begolli, K.N. (2016). Analogy and Higher Order Thinking: Learning Mathematics as an Example. Grantee Submission, Policy Insights from the Behavioral and Brain Sciences, Vol. 3, No. 2, hal.160-168.

[28] Samo, D.D.; Darhim; \&Kartasasmita, B. (2017). Developing Contextual Mathematical Thinking Learning Model to Enhance Higher-Order Thinking Ability for Middle School Students. International Education Studies, Vol. 10, No.12, hal. 17-29.

[29] Shaw, D. (2004). Thoughful Literacy Using the Newspaper. Sun-Sentinel: News in Education (NIE)

[30] Syaban, M. (2010). Menumbuhkembangkan Daya dan Disposisi Matematis Siswa Sma Melalui Model Pembelajaran Investigasi. Online. Tersedia http://educare.efkipunla.net/index.php?option=com _frontpage\&Itemid=1. 12 mei 2011.

[31] Tanujaya, B., Mumu, J.\&Margono, G. (2017). The Relationship between Highe rder Thinking Skils and Academic Performance of Student in Mathematics Instruction. International Education Studies, Vol.10, No.11, hal. 78-85.

[32] Uka, N.K. (2015). Developing Entrepreneurial Skills in Secondary Schools Students Through Effective Mathematics Education in Aba, Nigeria. International Journal of Education, Learning, and Development, Vol. 3, No. 7, hal. 1-11. www.eajournals.org. 